Published in final edited form as:

J Allergy Clin Immunol Pract. 2016 ; 4(6): 1039-1052. doi:10.1016/j.jaip.2016.08.005.

\title{
Lung Disease in Primary Antibody Deficiencies
}

\author{
Edith Schussler, MDa, Mary B. Beasley, MD $^{\mathrm{b}}$, and Paul J. Maglione, MD, PhD ${ }^{\mathrm{a}}$ \\ a Department of Medicine, Division of Clinical Immunology, Icahn School of Medicine at Mount \\ Sinai, New York, NY \\ b Department of Pathology, Icahn School of Medicine at Mount Sinai, New York, NY
}

\begin{abstract}
Primary antibody deficiencies (PADs) are the most common form of primary immunodeficiency and predispose to severe and recurrent pulmonary infections which can result in chronic lung disease including bronchiectasis. Chronic lung disease is among the most common complications of PAD and a significant source of morbidity and mortality for these patients. However, the development of lung disease in PAD may not be solely the result of recurrent bacterial infection or a consequence of bronchiectasis. Recent characterization of monogenic immune dysregulation disorders and more extensive study of common variable immunodeficiency has demonstrated that interstitial lung disease (ILD) in PAD can result from generalized immune dysregulation and frequently occurs in the absence of pneumonia history or bronchiectasis. This distinction between bronchiectasis and ILD has important consequences in the evaluation and management of lung disease in PAD. For example, treatment of ILD in PAD typically utilizes immunomodulatory approaches in addition to immunoglobulin replacement and antibiotic prophylaxis which are the stalwarts of bronchiectasis management in these patients. Additionally, while all antibody deficient patients are at risk of developing bronchiectasis, ILD occurs in some forms of PAD much more commonly than others, suggesting that distinct but poorly understood immunological factors underlie development of this complication. Importantly, ILD can have earlier onset and may worsen survival more than bronchiectasis. Further efforts to understand the pathogenesis of lung disease in PAD will provide vital information for the most effective methods of diagnosis, surveillance, and treatment of these patients.
\end{abstract}

\section{Keywords}

common variable immunodeficiency; CVID; granulomatous interstitial lung disease; GLILD; interstitial lung disease; bronchiectasis; primary antibody deficiency

Corresponding author: Paul J. Maglione, MD, PhD, Department of Medicine, Icahn School of Medicine at Mount Sinai, 1425 Madison Ave, New York, NY 10029. Telephone: 212-659-9243, Fax: 212-987-5593. paul.maglione@ mssm.edu.

Publisher's Disclaimer: This is a PDF file of an unedited manuscript that has been accepted for publication. As a service to our customers we are providing this early version of the manuscript. The manuscript will undergo copyediting, typesetting, and review of the resulting proof before it is published in its final citable form. Please note that during the production process errors may be discovered which could affect the content, and all legal disclaimers that apply to the journal pertain.

The authors declare no conflicts of interest. 
Primary antibody deficiency (PAD) is the most common form of primary immunodeficiency and consists of a group of disorders with impaired antibody production. ${ }^{1}$ Yet, even though PADs account for more than half of all primary immunodeficiencies, ${ }^{2,3}$ the genetic basis for the majority of PAD cases remains undefined. ${ }^{4}$ PAD continues to be under-recognized by physicians and diagnostic delays of many years remain common. ${ }^{5}$ Delayed diagnosis can have significant consequences, including risk of severe acute infections and sequelae of inadequately controlled chronic infections. Respiratory symptoms including productive cough, wheeze, recurrent respiratory infections, and rhinosinusitus are the most common presenting features of PAD. ${ }^{6}$ Notably, worsening of chronic lung disease due to structural damage from severe or chronic infections is a paramount concern for PAD patients. ${ }^{7}$

Perhaps due to the prominent role of bacteria in lung diseases like bronchiectasis and pneumonia and the importance of antibodies in protection against bacteria, lung disease is a frequent issue for PAD patients. In addition to bacterial infection, respiratory viruses may also lead to pulmonary exacerbations, ${ }^{8}$ yet there is a paucity of data regarding the role of viruses in bronchiectasis or other forms of chronic lung disease in PAD. Increased recognition and usage of appropriate therapy in PAD patients has reduced the incidence of severe infections, including pneumonia, and improved survival. ${ }^{9}, 10$ However, lung disease can progress in PAD patients despite conventional treatment with $\operatorname{IgG}$ replacement therapy and/or antibiotic prophylaxis. ${ }^{7}$ Importantly, interstitial lung disease (ILD) and other pulmonary complications may not simply be the result of inadequately treated antibody deficiency or infection, but may actually be a consequence of immune dysfunction inherent to these patients.

\section{OVERVIEW OF PRIMARY ANTIBODY DEFICIENCY SYNDROMES}

PAD consists of a diverse group of disorders resulting from fundamental defects in the ability to produce effective antibody responses against pathogens. This antibody deficiency may be due to intrinsic B cell defects, but can also involve functional impairments of other immune cells that promote antibody responses. As these numerous types of PAD each have differing degrees of immunological compromise, non-infectious sequelae such as chronic lung disease, much like susceptibility to infection, varies by specific disorder. To aid in understanding the pulmonary complications that can emerge in PAD, it is helpful to briefly review different etiologies of PAD commonly affected by lung disease.

\section{Congenital agammaglobulinemia}

Congenital agammaglobulinemia results in profound absence of antibody, with marked reduction of all immunoglobulin (Ig) isotypes. This typically results from a genetic defect impairing expression or signaling of the pre-B cell receptor, leading to arrest of B cell development. X-linked agammaglobulinemia (XLA) accounts for approximately $85 \%$ of patients with congenital agammaglobulinemia and is due to mutations in the Bruton's tyrosine kinase (BTK) gene, which is carried on the X chromosome. ${ }^{11}$ Most BTK mutations result in a lack of BTK protein expression and a severe block in B cell differentiation, though there is some variability of presentation with a genotype-phenotype correlation. ${ }^{12}$ Autosomal recessive (AR) forms of congenital agammaglobulinemia have also been 
described, and the block in B cell development can be more severe than in XLA. ${ }^{13}$ In those with congenital agammaglobulinemia the onset of bacterial infections is typically after the first 6 months of life when maternal antibody acquired through the placenta has waned. The sinopulmonary tract is the site of infection in $60 \%$ of patients, but pyoderma, chronic conjunctivitis, gastroenteritis, arthritis, meningitis, osteomyelitis and septicemia are also seen. ${ }^{14}$ While infections with encapsulated bacteria like Haemophilus influenzae and Streptococus pneumoniae are the most frequent concern for these patients, susceptibility to certain viral infections, such as hepatitis and enteroviruses, may also be increased.

Diagnostic delay in congenital agammaglobulinemia is significant, with average age of diagnosis 2.6 years in those with family history and 5.4 years in those without. ${ }^{14}$

\section{Hyper IgM syndrome}

Hyper IgM (HIGM) syndrome includes a group of disorders with defective B cell isotype class switching resulting in low concentrations of $\operatorname{IgG}$ and $\operatorname{IgA}$ with normal to increased levels of IgM. The most common and severe form accounting for $70 \%$ of cases is $\mathrm{X}$-linked and results from absent $\mathrm{T}$ cell-dependent costimulation of $\mathrm{B}$ cells as a result of mutations in CD40 ligand (CD40L) making it truly a combined immunodeficiency. ${ }^{15}$ An extremely rare AR form of HIGM syndrome affecting the CD40 molecule has also been described. ${ }^{16}$ Both forms affecting CD40:CD40L interaction result in impaired Ig isotype class switching and T cell activation of phagocytic cells, leading to susceptibility not only to bacterial pathogens but also infections not typical for antibody deficiency alone, like Pneumocystis. The most common AR form of HIGM syndrome results from mutations in activation-induced cytidine deaminase (AID) which, along with HIGM syndrome due to AR mutations in another enzyme involved in class switch recombination called uracil DNA glycosylase (UNG), is characterized by profound lymphoid hyperplasia in addition to impaired Ig isotype class switching. ${ }^{17}$ Both the X-linked and AR forms of HIGM syndrome predispose to sinopulmonary and gastrointestinal infections as well as autoimmune disease. ${ }^{18}$

\section{Selective IgA deficiency}

Selective IgA deficiency (IgAD), is the most common primary immunodeficiency overall, with a prevalence of about 1 in 600 individuals in Europe and North America. ${ }^{19}$ It is defined as a serum $\operatorname{IgA}$ of less than $7 \mathrm{mg} / \mathrm{dL}$ with normal $\operatorname{IgM}$ and $\operatorname{IgG}$ levels in individuals of 4 years of age or older. ${ }^{20}$ Approximately two-thirds of individuals identified with IgAD are asymptomatic without any increased occurrence of infections, while the remaining one-third suffer from bacterial infections, most often of the respiratory tract, as well as gastrointestinal disorders, autoimmunity, and atopy. ${ }^{21,22}$ There may be a moderately increased risk of cancer, in particular of the gastrointestinal tract, associated with $\operatorname{IgAD} .^{23}$ In a recent study of 2100 Swedish individuals with IgAD it was found that individuals with IgA deficiency are more likely to have a record of any infection compared to age matched controls with a risk difference of $17.4 \% .{ }^{24}$ Several studies have shown an increased incidence of IgG subclass deficiency among symptomatic patients with IgAD, particularly the $\operatorname{IgG} 2$ subclass which has the greatest role in recognizing carbohydrate antigens. ${ }^{19}$ Sinopulmonary infections, mostly due to bacteria including $H$. influenzae and $S$. pneumoniae, are the most common manifestation of symptomatic IgAD and, in some patients, recurrent and chronic infections lead to bronchiectasis. ${ }^{21,25}$ Though the genetic cause of IgAD is unknown in most cases, the 
common finding is a maturation defect in B cells resulting in failure to develop into $\operatorname{Ig} \mathrm{A}$ secreting plasma cells. ${ }^{21,25-27}$ A higher frequency of IgAD has been found within families in which common variable immunodeficiency (CVID) has been diagnosed and progression of IgAD to CVID has been observed in a number of cases, suggesting the two diseases may be related. ${ }^{28-30}$ Notably, genetic defects of transmembrane activator and CAML interactor (TACI) have been found in association with both IgAD and CVID. ${ }^{31,32}$

\section{IgG subclass deficiency and specific antibody deficiency}

Selective IgG subclass deficiency is defined as a lack of one or more Ig subclasses $\left(<5^{\text {th }}\right.$ percentile) with levels of total $\operatorname{IgG}, \operatorname{IgA}$, and $\operatorname{IgM}$ in the normal range measured on at least two occasions at least one month apart in a symptomatic patient. ${ }^{33}$ As with IgAD, many individuals without recurrent infections and otherwise asymptomatic have low IgG subclass levels, making the clinical significance of IgG subclass deficiency unclear. Impaired polysaccharide vaccine responses can be found in those with IgG2 subclass deficiency and associated infections are most commonly those with encapsulated bacteria. Impaired response to polysaccharide vaccination can also be found in the absence of low total IgG or IgG subclasses, known as specific antibody deficiency. ${ }^{34}$ Impaired antibody response to pneumococcal polysaccharide vaccination is also seen in patients with IgAD. ${ }^{35}$ IgG subclass deficiency and impaired pneumococcal response are also seen as components of other primary immunodeficiencies, including Wiskott-Aldrich syndrome, ataxia-telangiectasia, and monogenic immune dysregulation disorders that will be discussed further. ${ }^{22,} 33,36-38$

\section{Common variable immunodeficiency}

CVID is the most commonly encountered symptomatic PAD with an estimated prevalence of between 1:25,000 and 1:50,000, affecting men and women equally. ${ }^{39}$ It consists of a heterogeneous group of disorders characterized by low levels of IgG and IgA, with or without low IgM levels, along with defective antibody responses. ${ }^{40}$ In some cases, CVID is associated with an increased incidence of autoimmunity, granuloma, lymphoid hyperplasia, and malignancy. ${ }^{41}$ While the underlying defect of CVID impairs differentiation of B cells into antibody-producing plasma cells and isotype-switched memory B cells, T cell abnormalities are seen in approximately $50 \%$ of patients. ${ }^{42,43}$ Autosomal mutations have been identified as genetic etiologies of a small subset of CVID patients, but the molecular pathogenesis is not known in most cases. CVID is most commonly diagnosed in the second to fourth decade of life, though the age of onset is quite variable. Recurrent sinopulmonary infections are the most frequent presentation. While common pathogens affecting CVID patients include the encapsulated bacteria seen in those with other forms of PAD, atypical infections with organisms such as Mycoplasma and Ureaplasma, have also been described. ${ }^{33}$ With widespread usage of IgG replacement therapy, the emergence of "non-infectious" complications, which include autoimmune cytopenias along with gastrointestinal, liver, lung disease, and malignancy, have emerged as the most important cause of morbidity and mortality in CVID patients. ${ }^{44-46}$

\section{Monogenic causes of PAD and lung disease}

In recent years, genetic etiologies of monogenic immune dysregulation disorders with PAD have been described. This review will discuss those in which chronic lung disease is 
frequently found and PAD is noted in the majority of cases. Cytotoxic T lymphocyteassociated protein 4 (CTLA-4) haploinsufficiency is an autosomal dominant (AD) disorder with variable penetrance characterized by hypogammaglobulinemia and recurrent infections as well as autoimmune phenomena and lymphocytic organ infiltration. ${ }^{47,} 48$ CTLA-4 is an inhibitory checkpoint protein expressed constitutively on regulatory $\mathrm{T}$ cells and also expressed by activated T cells that inhibits cellular proliferation upon ligation. ${ }^{49,}{ }^{50} \mathrm{In}$ addition to antibody deficiency and progressive loss of circulating B cells with concurrent accumulation of B cells in non-lymphoid organs, CTLA-4 haploinsufficiency also causes dysregulation of regulatory $\mathrm{T}$ cells and hyperactivation of effector $\mathrm{T}$ cells.

Lipopolysaccharide-responsive and beige-like anchor protein (LRBA) deficiency is a primary immunodeficiency caused either by homozygous or compound heterozygous mutations of LRBA that lead to loss of protein expression. LRBA is a cytosolic protein highly expressed in B and T cells as well as other cell lineages and is involved in cytoskeleton assembly, signal transduction, vesicular trafficking, transcriptional regulation, chromatin dynamics and apoptosis. ${ }^{51,52}$ Importantly, LRBA co-localizes with CTLA-4 within recycling endosomes and the trans-golgi network and has been implicated in the maintenance of intracellular stores of CTLA-4 in T cells. ${ }^{53}$ Manifestations of LRBA deficiency typically begin in early childhood and include chronic diarrhea, autoimmune disorders, and organomegaly in addition to hypogammaglobinemia and recurrent respiratory infections. ${ }^{54,55}$ Serious neurologic dysfunction including myasthenia gravis, cerebral lesions and nervous tissue atrophy has also been seen in $23 \%$ of patients. Autoimmune features, most commonly autoimmune hemolytic anemia and immune thrombocytopenic purpura are prominent in this immune disorder and seen in up to $61 \%$ of patients. ${ }^{54}$

Activated phosphoinositide 3-kinase $\delta$ (PI3K $\delta$ ) syndrome is an AD disease characterized by recurrent infections, lymphoproliferation, and autoimmunity, with PAD also found in most patients, particularly reduced levels of $\operatorname{IgG} 2 .{ }^{36}$ The immune dysregulation results from gainof-function (GOF) mutations in the PIK3CD gene encoding the p1108 subunit of PI3K expressed in lymphocytes, leading to increased enzyme activity, excessive CD8+ T cell proliferation, CD4+ T cell lymphopenia, reduced isotype-switched B cells, variable levels of IgM along with hypogammaglobulinemia, IgG subclass deficiency, or poor immune responses to the pneumococcal vaccine. ${ }^{36,56,57}$ Patients often present in childhood with recurrent respiratory infections, lymphadenopathy, nodular lymphoid hyperplasia of mucosal surfaces, and increased susceptibility to EBV and CMV viremia. Autoimmune complications, including refractory thrombocytopenia and anemia, and inflammatory bowel disease are also features as is an increased susceptibility to non-EBV associated

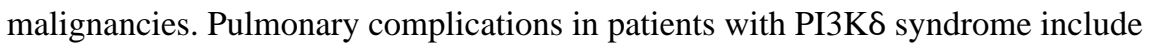
lymphocytic nodules, bronchiectasis, and airway damage due to recurrent respiratory infections. ${ }^{36,56}$

Signal transducer and activator of transcription 3 (STAT3) GOF mutations are AD and were discovered after examining the exomes of patients with early-onset and severe multi-organ autoimmunity. ${ }^{58-60}$ These patients also have hypogammaglobulinemia, infection susceptibility, and lymphoproliferative complications as with previous monogenic disorders described. STAT3 is an important transcription factor that regulates the expression of target 
genes involved in proliferation, apoptosis, and differentiation. It is important in both the innate and adaptive immune responses, and is critical to the development of IL-17 producing CD4+ T cells (Th17 cells). ${ }^{61,} 62$ Although the phenotypes are highly variable, patients with STAT3 GOF typically have postnatal short stature and early onset hematologic autoimmunity followed by lymphoproliferation leading to enteropathies and/or lymphocytic ILD. Other autoimmune manifestations include type 1 diabetes, thyroid disease, hepatitis, and skin disease. The immune dysregulation leads to recurrent and severe infections particularly of the respiratory tract and susceptibility to opportunistic infections including mycobacterial disease. Hematologic abnormalities include lymphopenia and hypogammaglobulinemia associated with decreased isotype-switched memory B cells. ${ }^{60}$ Elevation of double negative $\mathrm{T}$ cells in the blood may also be seen.

\section{PULMONARY INFECTIONS IN PAD}

The principal clinical manifestations of PAD are recurrent bacterial infections of the upper and lower respiratory tract. ${ }^{33}$ Chronic bronchitis and recurrent pneumonia are commonly seen, especially prior to initiation of $\operatorname{IgG}$ replacement. Risk of pneumonia is particularly substantial in PAD patients as it is reported that $75-84 \%$ of CVID patients $9,10,63$ and about $60-83 \%$ of XLA patients experience at least one episode of pneumonia prior to diagnosis. ${ }^{14,64-66}$ Early identification of pulmonary involvement and prompt intervention with prophylactic antibiotics and/or IgG replacement therapy can decrease frequency of infections and improve morbidity and mortality. ${ }^{9}, 10,67-70$ Delay in diagnosis on the other hand is associated with progression to obstructive airway disease, chronic atelectasis, bronchiectasis, and pulmonary fibrosis. ${ }^{6,65}$

Predisposition to sinopulmonary infections is largely due to absence of antibody that would typically prevent mucosal attachment, cellular entry, and/or facilitate destruction of bacterial or viral pathogens. Encapsulated bacteria are the most common pathogens isolated from the sputum of patients with PAD. ${ }^{71,72}$ Deficient antibody-antigen interaction may also result in impaired complement activation, depressed chemotaxis, and deficient opsonization and phagocytosis of pathogenic organisms. ${ }^{69}$ Interestingly, it has been suggested that recurrent bacterial pneumonia in CVID patients with low IgM may be due to the loss of opsonization and phagocytosis as a result of IgM deficiency that is not compensated for by $\operatorname{IgG}$ replacement therapy. ${ }^{73}$ Patients with AR HIGM syndrome due to class switch recombination defects had a lower incidence of acute respiratory tract infections and bronchiectasis as well as a significantly lower risk of infection with non-typeable $H$. influenzae compared to agammaglobulinemic patients. ${ }^{74}$

Approximately 30-60\% of CVID patients develop chronic lung disease. ${ }^{75}$ The most common chronic pulmonary finding is likely to be bronchiectasis, ${ }^{76}$ however ILD is also frequently found and has a higher rate of mortality. ${ }^{45,77}$ In CVID, it has been found that upper and lower respiratory tract infections caused by encapsulated bacteria, such as $H$. influenzae and $S$. pneumoniae, can lead to acute complications including pleurisy, empyema, and bronchospasm, ${ }^{63}$ which are important clinical manifestations leading to chronic lung disease, bronchiectasis, and possibly death. As in CVID, patients with XLA and AR forms of agammaglobulinemia are highly susceptible to infections by encapsulated bacteria. 
However, the risk of chronic lung disease and bronchiectasis is higher in those with CVID than XLA, which may be secondary to the fact that XLA is diagnosed earlier and thus treated more promptly or perhaps due to the more profound T cell defects seen in CVID. ${ }^{63}$ As HIGM syndrome due to defects of CD40 or CD40L is a combined immunodeficiency due to defective $\mathrm{T}$ cell interactions with monocytes, dendritic cells, and $\mathrm{B}$ cells these patients have broader infection susceptibility that includes Pneumocystis, herpes family viruses (including cytomegalovirus), Cryptosporidium, Cryptococcus, Candida, Histoplasma, and Bartonella. $^{78}$

Bronchiectasis is an irreversible dilation of the bronchial airways caused by inflammatory destruction of airway walls ${ }^{79}$ and is the most common complication of recurrent pneumonia. ${ }^{63}$ The pathophysiology involves a vicious cycle of recurrent infections leading to airway inflammation and impaired host defense allowing for bacterial colonization and further chronic progressive inflammation eventually resulting in permanent tissue damage. ${ }^{80}$ Patients usually present with shortness of breath, chronic cough, purulent sputum and occasionally hemoptysis. It is characterized by mild to moderate airflow obstruction that tends to worsen over time, with loss of forced expiratory volume in one second (FEV1). ${ }^{81-83}$ The diagnosis is made by high resolution computed tomography (CT) and may be missed on conventional chest X-ray (Figure 1A). Despite IgG replacement therapy and/or antibiotic prophylaxis, some patients with PAD still develop bronchiectasis or have worsening of this complication. ${ }^{84-86}$ Hurst et al showed that patients with PAD have a greater inflammatory response in their airways and systemic circulation than immunocompetent patients with a similar CT-extent of bronchiectasis. ${ }^{87}$ Once bronchiectasis has developed, colonization by Pseudomonas aeruginosa or non-tuberculous mycobacteria may result in further respiratory decline and complicate management. ${ }^{63,88}$

In CVID patients followed at Mount Sinai, those with bronchiectasis were significantly more likely to have CD4+ T cell counts below 700 cells $/ \mu \mathrm{L}$, history of pneumonia, and older age. ${ }^{89}$ Other studies have also linked history of pneumonia and low IgM levels with the development of bronchiectasis in CVID..$^{90,91}$ As precursor findings to bronchiectasis such as bronchial wall thickening can be identified on a CT scan,,${ }^{92}$ baseline or surveillance imaging may be indicated for CVID patients with low CD4+ T cell counts, history of pneumonia, or low serum IgM levels. More subtle antibody deficiencies, such as specific antibody deficiency and IgG subclass deficiency, seem to increase risk of developing bronchiectasis in some patients, both with and without concurrent IgAD. ${ }^{93-97}$ In PI3K $\delta$ syndrome patients in which $100 \%$ of those tested had impaired response to pneumococcal vaccination and $91 \%$ had low IgG2 levels, $75 \%$ had CT evidence of bronchiectasis. ${ }^{36}$

For treatment of bronchiectasis in PAD patients, inhaled corticosteroids with or without long-acting $\beta$-agonist, long-term macrolide antibiotic therapy, increased IgG replacement dosage to goal trough of $1000 \mathrm{mg} / \mathrm{dL}$, and pulmonary rehabilitation may be utilized at the physician's discretion as supporting data is limited (Figure 2). ${ }^{98-101}$ The use of long-term macrolide therapy is based upon studies of non-cystic fibrosis bronchiectasis that vary in duration of treatment from 8 weeks to 24 months, but bronchiectasis in PAD has not specifically been assessed and thus the optimal treatment for these patients is not known. The most studied macrolide for bronchiectasis treatment is azithromycin, for which 
regimens include $250 \mathrm{mg}$ daily or $500 \mathrm{mg}$ three days a week, but clarithromycin and erythromycin have also been used with success. ${ }^{101-103}$

\section{INTERSTITIAL LUNG DISEASE}

\section{Incidence}

Due to its distinct immunological and pathological characteristics, ILD should be considered separately from lung damage related to chronic or recurrent pulmonary infections in PAD patients. The development of ILD does not require the presence of bronchiectasis and is associated with different clinical and immunological characteristics, such as elevated rather than reduced serum IgM levels. ${ }^{44,75,89,91}$ Based upon the results of relatively small studies, one can surmise that ILD occurs in at least 10-20\% of CVID patients. ${ }^{104}$ However, the exact incidence of ILD is unclear because most large studies have not distinguished ILD from other forms of chronic lung disease, such as bronchiectasis. We found CT evidence of ILD in 39 of 61 CVID patients referred to Mount Sinai, which suggests that the incidence may be underestimated. ${ }^{89}$ The most common radiologic findings of ILD in CVID are pulmonary nodules, ground glass opacities, and mediastinal lymphadenopathy (Figure 1B \& 1C). Adding further complication to the significance of radiologic findings in CVID is the fact that despite abnormal CT findings pulmonary function does not always decline. ${ }^{86,105}$ Typical symptoms of ILD in CVID patients are chronic cough and shortness of breath and are hence quite nonspecific. Biopsies may be necessary for the diagnosis of ILD in PAD and to differentiate pulmonary nodules from malignancies, particularly lymphomas, which may arise in the lungs of these patients. ${ }^{106}$ Pulmonary function testing may reveal obstructive pathology, particularly in PAD patients with bronchiectasis, or restrictive lung disease resulting in reductions of forced vital capacity (FVC) and/or diffusing capacity for carbon monoxide (DLCO) as a consequence of ILD. ${ }^{86,} 107$ Significant decrease of DLCO may precede decline of FVC in PAD patients with ILD, and therefore should be included in pulmonary function assessment of these patients. ${ }^{105}$

ILD appears to be a relatively common feature of CTLA-4 haploinsufficiency, with pulmonary nodules and lymphocytic lung infiltrates frequently seen. ${ }^{47}$ Granulomatous infiltrative lung disease was found in 8 of 12 patients with CTLA- 4 haploinsufficiency in one study. ${ }^{48}$ Pulmonary abnormalities including bronchiectasis, lymphocytic infiltrates, and granuloma were found 52\% of patients in one study of LRBA deficiency and lymphocytic ILD specifically was noted in 3 of 31 patients with LRBA deficiency in another report. ${ }^{54,55}$ ILD can also occur in patients with STAT3 GOF and include fibrosing pneumonitis and lymphocytic interstitial pneumonia. ${ }^{58,59} \mathrm{ILD}$ is occasionally seen in IgAD, particularly those with concurrent autoimmunity and IgG subclass deficiency, and can mimic the radiographic nodules and lung function impairment seen in CVID (Figure 1D). ${ }^{94,108,109}$ In stark contrast to the frequency seen in CVID and some monogenic immune dysregulation disorders with PAD, ILD is not reported in numerous studies of large cohorts and registries of HIGM syndrome patients, including those with X-linked and AR forms. ${ }^{15}, 110,111$ Similarly, ILD also appears to be very rare or absent in congenital agammaglobulinemia patients. Two studies found CT evidence of ILD in CVID patients but not in XLA. ${ }^{64,112}$ Likewise, there is no mention of ILD in numerous clinical reports of XLA patients. ${ }^{113-116}$ 
As XLA is characterized by marked absence of B cells but a retained T cell compartment, the development of ILD in PAD may be dependent on the presence of B cells and/or dysregulation of $\mathrm{T}$ cells.

\section{Pathogenesis}

The ILD associated with PAD most commonly contains forms of benign lymphoproliferative pathology, with follicular bronchiolitis, nodular lymphoid hyperplasia, and lymphocytic interstitial pneumonia (LIP) being the most typical. ${ }^{77,89,117}$ Granulomatous inflammation is also frequently seen in CVID patients in lungs as well as other organs. ${ }^{118}$ Organizing pneumonia is also found in PAD patients and is non-specific reactive inflammation that results from diverse causes of lung injury and is characterized by plugs of granulation tissue and whorls of fibroblasts, known as Masson bodies, in the alveolar spaces. ${ }^{119}$ Biopsy of ILD in CVID patients can show both benign lymphoproliferative lung disease and granulomatous inflammation, with organizing pneumonia often also observed as well, leading to usage of the encompassing term granulomatous lymphocytic interstitial lung disease (GLILD) to indicate the heterogeneous nature of this pathology. ${ }^{120}$ However, GLILD is a term used exclusively for CVID and other immunodeficiency disorders and may not be a term familiar to all pathologists and pulmonologists. Moreover, where exactly the line is drawn for lung pathology to be termed GLILD is nebulous as LIP alone can have both granulomatous inflammation and organizing pneumonia as features. ${ }^{121,122}$ Accordingly, clinical immunologists must be familiar with the full spectrum of ILD pathology seen in PAD patients so that treatment is administered appropriately (Table I).

In a series of twelve CVID patients that had lung biopsies and were followed at Mount Sinai, eleven had pathology consistent with benign lymphoproliferative lung disease, including follicular bronchiolitis, LIP, and atypical or reactive lymphoid hyperplasia. ${ }^{89}$ Follicular bronchiolitis manifests as hyperplasia of lymphoid follicles near bronchi and bronchioles (Figure 3A). ${ }^{122}$ LIP is thought to be a progression of this pulmonary lymphoid hyperplasia defining follicular bronchiolitis into involvement of the pulmonary interstitium, resulting in expansion of the alveoli septum (Figure 3B). As mentioned, granulomas can be a feature of benign lymphoproliferative ILD in PAD and can occur in conjunction with follicular bronchiolitis and/or LIP (Figure 3C). Nodular lymphoid hyperplasia is also seen in PAD, particularly in patients with CVID or PI3K $\delta$ syndrome, consisting of interstitial inflammation with more well-demarcated follicles than LIP and may be a precursor of mucosal-associated lymphoid tissue lymphomas but it's exact relationship with malignancy is unclear (Figure 3D). ${ }^{117,} 122$ The ectopic B cell follicles that characterize these benign lymphoproliferative ILD develop and express markers of germinal centers and proliferation despite the B cell maturation defects inherent to PAD (Figure 4). ${ }^{107}$ This observation is notable because CVID is characterized by poor T cell-dependent isotype-switched antibody responses to vaccination and impaired development of memory B cells, both of which classically utilize germinal center reactions. ${ }^{123}$ Such ectopic lymphoid tissue can serve significant functions in both immune-mediated protection and disease pathology, directing host defense against respiratory pathogens and cancer but also amplifying chronic inflammatory disease. ${ }^{124}$ In CVID, this lymphoid hyperplasia and formation of pulmonary 
ectopic follicles appears to contribute to progression of ILD because B cell depletion with rituximab improves pulmonary function and radiologic findings. ${ }^{105}$, 125, 126

Importantly, the lymphoid hyperplasia occurring in the lungs is consistent with the generalized lymphoid hyperplasia occurring elsewhere in the same patients, as persistent lymphadenopathy and splenomegaly are both strongly associated with ILD in CVID. ${ }^{44,77,89,127,128}$ ILD may simply be a manifestation of immune dysregulation in immunocompromised patients, as it is increasingly recognized that immune deficiency, autoimmunity, and lymphoproliferation frequently go hand-in-hand. ${ }^{129-131}$ Notably, autoimmunity is more frequent in CVID patients with ILD. ${ }^{43,}, 87,124,125$ Further evidence of a role of intrinsic immune dysregulation is evidenced by the fact that CTLA-4 haploinsufficiency, LRBA deficiency, and STAT3 GOF as well as other immunological disorders such as Sjogren's syndrome can lead to benign lymphoproliferative ILD in the absence of apparent pulmonary infection. ${ }^{43,89,127,128,132,133}$ Other characteristics that can be useful to differentiate CVID patients with ILD from those without this complication are increased CD4:CD8 ratio, elevated serum IgM levels, and reduced isotype-switched memory B cells (Table II). ${ }^{44,77,89}$

While immune dysregulation alone could explain the emergence of ILD, infection is also a possible etiology. Viral infections have been linked with development of lymphoproliferative disorders, particularly in immunocompromised patients. Human herpes virus 8 (HHV-8) has been suggested as an etiology in one report of CVID ILD though remains to be confirmed. ${ }^{134}$ As postulated for Castleman's disease, there may be both HHV-8 associated and non-associated forms of lymphoproliferative disease in CVID. ${ }^{135}$ Another possible viral etiology is Epstein-Barr virus (EBV), which has been linked to benign lymphoproliferative disorders in patients immunocompromised by human immunodeficiency virus infection or transplant immunosuppression. ${ }^{136-138}$ One study found EBV in 2 of 10 biopsies of hyperplasic lymph nodes from CVID patients. ${ }^{139}$ However, we found no evidence of EBV infection in lung biopsies of a series of CVID patients with ILD at Mount Sinai ${ }^{107}$ and such an association has not been reported by others. More sensitive detection methods, such as next generation sequencing, may be needed to identify causative pathogens. ${ }^{140}$

CVID patients with ILD can be erroneously diagnosed with sarcoidosis because the radiologic findings are similar and non-necrotizing granulomas are features of both conditions. However, there are numerous clinical and radiological features that distinguish CVID ILD and sarcoidosis (Table III). CVID ILD can typically be distinguished from sarcoidosis radiologically by larger pulmonary nodules and the fact that the upper lung zones are not preferentially involved. ${ }^{141}$ Moreover, biopsies of CVID patients will much more commonly demonstrate follicular bronchiolitis, LIP, or other forms of benign lymphoproliferative ILD when compared with sarcoidosis. Additionally, hypogammaglobulinemia, decreased levels of isotype-switched memory B cells, and distinctive sequelae of CVID like autoimmune cytopenias, nodular regenerative hyperplasia of the liver, recurrent infections, and splenomegaly can help differentiate the diagnoses. As for why granulomas form in these patients, granulomatous inflammation is non-specific and may simply be a consequence of excessive lymphoproliferation for which some PAD patients, particularly those with CVID and monogenic immune dysregulation disorders, have 
a particular predilection. Notably, skin biopsies from patients with unrestrained lymphoproliferation as a result of autoimmune lymphoproliferative syndrome show granulomatous pathology. ${ }^{142}$ The progression of lymphoid hyperplasia to granulomatous inflammation is also observed in broader patient populations, where granulomatous inflammation was found in $22 \%$ of lymph node fine needle aspirations done to evaluate lymphadenopathy ${ }^{143}$ as well as 20 of 38 biopsies for mediastinal lymphadenopathy in patients without CVID or known primary immune dysregulation disorder. ${ }^{144}$

\section{Management}

ILD is typically present at the time of CVID diagnosis and noted in younger patients overall, so it appears that a particular subset of CVID patients is most susceptible to this complication. $46,89,104$ Thus, while all PAD patients require attention to respiratory symptoms, ample use of pulmonary function testing, and concern for the development of bronchiectasis, repeated chest $\mathrm{CT}$ scans to screen asymptomatic patients for the sudden emergence of ILD may be unnecessary in many cases. This may particularly be true for CVID patients without associated clinical and laboratory characteristics (Table II) or other PAD where ILD has not been reported, such as XLA, and risks of repeated CT scans outweigh unlikely benefits. ${ }^{145-147}$ Conversely, in CVID patients with the associated clinical and laboratory characteristics, or in those with monogenic immune dysregulation disorders associated with ILD, presence of respiratory symptoms should trigger evaluation of ILD. Thus, we advise strong consideration of clinical symptoms, pulmonary function test results, type of PAD, as well as clinical and laboratory characteristics when determining the usage of CT scans in this patient population.

First-line therapy in patients with concern for ILD includes ensuring adequate IgG replacement dosage as this intervention alone can occasionally resolve the lung disease and we found troughs of $1000 \mathrm{mg} / \mathrm{dL}$ significantly less likely to be associated with pulmonary function decline. ${ }^{105,148}$ Additionally, usage of inhaled corticosteroids with or without bronchodilators as well as prophylactic macrolide therapy can be used in patients with modest symptoms as both therapies can have efficacy in follicular bronchiolitis. ${ }^{149-151}$ In those with daily activity limited by respiratory symptoms, objective pulmonary function decline of [.greaterequal] $10 \%$ predicted FVC or $\leq 15 \%$ predicted DLCO, or enlarging pulmonary nodule lung biopsy is advisable. Thoracoscopic or open lung biopsies are preferable over endobronchial specimens because they offer greater tissue yield and improved diagnosis because, as mentioned earlier, the pathology in PAD patients can be heterogenous. Oral corticosteroids can occasionally be effective for ILD in PAD patients, though there are concerns for immunosuppression and consequences of long-term corticosteroid usage in addition to the fact that many cases are refractory to this therapy. ${ }^{152}$ As a result, numerous immunomodulatory agents, including azathioprine, cyclosporine, cyclophosphamide, hydroxychloroquine, methotrexate, and mycophenolate mofetil, have been tried with mixed results. ${ }^{125,153}$ Use of infliximab has had reported efficacy in CVID patients where granulomatous inflammation is prominent. ${ }^{154,155}$ In our experience, rituximab can be effective in CVID patients with benign lymphoproliferative ILD, but improvement is transient and the therapy needs to be repeated. ${ }^{107}$ Better treatment success for CVID ILD may be found by utilizing combination approaches such as the usage of 
azathioprine, mercaptopurine, or mycophenolate mofetil along with rituximab, but this approach requires prolonged immunosuppression that includes repeating rituximab every 6 months. ${ }^{126}$ Chronic usage of immunosuppressive therapy may increase risk of infection or malignancy as well as have numerous adverse effects. ${ }^{156,157}$ Therefore, it is preferable to limit these treatments to those with pulmonary function or symptomatic decline as some PAD patients with radiologic evidence of ILD have stable lung disease. ${ }^{105} \mathrm{~A}$ suggested approach to the management of ILD in PAD is outlined in Figure 5. An additional parameter that may be useful to identify those CVID patients with progressive ILD is serum IgM, which we found to increase in most patients who had significant pulmonary function decline. ${ }^{105}$ Lung transplant has been conducted in particularly dire cases of pulmonary disease in CVID, but outcomes have generally been poor and this intervention is typically considered a last resort. ${ }^{158}$ Much work remains necessary in this area as no controlled clinical trials have been conducted for the treatment of ILD in PAD patients. Moreover, novel treatment strategies are needed as many patients are refractory to current therapies or require perpetual rounds of immunosuppressive treatment with inherent risks.

Recent identification of monogenic immune dysregulation disorders that develop ILD may provide useful information to devise more effective therapy for PAD patients with this complication. Treatment with abatacept improved CT chest findings and pulmonary function in three patients with LRBA deficiency and ILD, most likely due the role of LRBA in CTLA-4 trafficking. ${ }^{53}$ While it stands to reason that abatacept could prove to be similarly effective in CTLA-4 haploinsufficiency patients with ILD, the characteristics of CVID ILD patients that would benefit from this therapy remain to be defined. Rapamycin has been effective for treating lymphoid hyperplasia in patients with PI3K $\delta$ syndrome, presumably through the suppression of mTOR signaling in hyperactive effector T cell responses, ${ }^{56}$ and may prove to be useful as therapy for ILD in PADs with similarly low ratio of naïve to effector T cells. Further studies are necessary to determine whether CVID patients with immunological characteristics mimicking that of specific monogenic immune dysregulation disorders would benefit from similarly targeted therapy.

\section{SUMMARY}

Lung disease is a common complication of PAD that can worsen morbidity and mortality. Importantly, chronic lung disease in these patients can take the form of bronchiectasis or ILD. While bronchiectasis seems clearly to be a consequence of persistent infection and is associated with pneumonia history, ILD susceptibility varies among forms of PAD, is associated with autoimmune cytopenias, multi-organ lymphoproliferation, and distinct immunological characteristics due to incompletely defined features of immune dysregulation. More research is needed to unravel the underlying pathogenesis of lung disease in PAD to improve the diagnosis and surveillance of this important complication as well as devise targeted therapies that are safer and more effective than those currently available.

\section{ACKNOWLEDGEMENTS}

We thank Charlotte Cunningham-Rundles for thoughtful discussion and guidance. 
The preparation of this review was not supported by any specific grant from funding agencies in the public, commercial, or not-for-profit sectors.

\section{ABBREVIATIONS}
AD
autosomal dominant
AR
autosomal recessive
CTLA-4 cytotoxic T lymphocyte-associated protein 4
CVID common variable immunodeficiency
DLCO diffusing capacity for carbon monoxide
FEV1 forced expiratory volume in one second
FVC forced vital capacity
GOF gain-of-function
GLILD granulomatous lymphocytic interstitial lung disease
HIGM hyper IgM
Ig immunoglobulin
IgAD selective IgA deficiency
ILD interstitial lung disease
LRBA lipopolysaccharide-responsive and beige-like anchor protein
PAD primary antibody deficiency
PI3K8 phosphoinositide 3-kinase
STAT3 signal transducer and activator of transcription 3
XLA X-linked agammaglobulinemia

\section{REFERENCES}

1. Durandy A, Kracker S, Fischer A. Primary antibody deficiencies. Nat Rev Immunol. 2013; 13:51933. [PubMed: 23765059]

2. Boyle JM, Buckley RH. Population prevalence of diagnosed primary immunodeficiency diseases in the United States. J Clin Immunol. 2007; 27:497-502. [PubMed: 17577648]

3. Joshi AY, Iyer VN, Hagan JB, St Sauver JL, Boyce TG. Incidence and temporal trends of primary immunodeficiency: a population-based cohort study. Mayo Clin Proc. 2009; 84:16-22. [PubMed: 19121249]

4. Keller MD, Jyonouchi S. Chipping away at a mountain: genomic studies in common variable immunodeficiency. Autoimmun Rev. 2013; 12:687-9. [PubMed: 23201919]

5. Cunningham-Rundles C. How I treat common variable immune deficiency. Blood. 2010; 116:7-15. [PubMed: 20332369]

6. Wood P, Network UKPI. Primary antibody deficiencies: recognition, clinical diagnosis and referral of patients. Clin Med (Lond). 2009; 9:595-9. [PubMed: 20095309] 
7. Gregersen S, Aalokken TM, Mynarek G, Fevang B, Holm AM, Ueland T, et al. Development of pulmonary abnormalities in patients with common variable immunodeficiency: associations with clinical and immunologic factors. Ann Allergy Asthma Immunol. 2010; 104:503-10. [PubMed: 20568383]

8. Kainulainen L, Vuorinen T, Rantakokko-Jalava K, Osterback R, Ruuskanen O. Recurrent and persistent respiratory tract viral infections in patients with primary hypogammaglobulinemia. $\mathrm{J}$ Allergy Clin Immunol. 2010; 126:120-6. [PubMed: 20541246]

9. Busse PJ, Razvi S, Cunningham-Rundles C. Efficacy of intravenous immunoglobulin in the prevention of pneumonia in patients with common variable immunodeficiency. J Allergy Clin Immunol. 2002; 109:1001-4. [PubMed: 12063531]

10. Orange JS, Grossman WJ, Navickis RJ, Wilkes MM. Impact of trough IgG on pneumonia incidence in primary immunodeficiency: A meta-analysis of clinical studies. Clin Immunol. 2010; 137:21-30. [PubMed: 20675197]

11. Vetrie D, Vorechovsky I, Sideras P, Holland J, Davies A, Flinter F, et al. The gene involved in Xlinked agammaglobulinaemia is a member of the src family of protein-tyrosine kinases. Nature. 1993; 361:226-33. [PubMed: 8380905]

12. Lopez-Granados E, Perez de Diego R, Ferreira Cerdan A, Fontan Casariego G, Garcia Rodriguez MC. A genotype-phenotype correlation study in a group of 54 patients with X-linked agammaglobulinemia. J Allergy Clin Immunol. 2005; 116:690-7. [PubMed: 16159644]

13. Conley ME, Dobbs AK, Farmer DM, Kilic S, Paris K, Grigoriadou S, et al. Primary B cell immunodeficiencies: comparisons and contrasts. Annu Rev Immunol. 2009; 27:199-227. [PubMed: 19302039]

14. Winkelstein JA, Marino MC, Lederman HM, Jones SM, Sullivan K, Burks AW, et al. X-linked agammaglobulinemia: report on a United States registry of 201 patients. Medicine (Baltimore). 2006; 85:193-202. [PubMed: 16862044]

15. Winkelstein JA, Marino MC, Ochs H, Fuleihan R, Scholl PR, Geha R, et al. The X-linked hyperIgM syndrome: clinical and immunologic features of 79 patients. Medicine (Baltimore). 2003; 82:373-84. [PubMed: 14663287]

16. Ferrari S, Giliani S, Insalaco A, Al-Ghonaium A, Soresina AR, Loubser M, et al. Mutations of CD40 gene cause an autosomal recessive form of immunodeficiency with hyper IgM. Proc Natl Acad Sci U S A. 2001; 98:12614-9. [PubMed: 11675497]

17. Davies EG, Thrasher AJ. Update on the hyper immunoglobulin M syndromes. Br J Haematol. 2010; 149:167-80. [PubMed: 20180797]

18. Duarte-Rey C, Bogdanos DP, Leung PS, Anaya JM, Gershwin ME. IgM predominance in autoimmune disease: genetics and gender. Autoimmun Rev. 2012; 11:A404-12. [PubMed: 22178509]

19. Wang N, Hammarstrom L. IgA deficiency: what is new? Curr Opin Allergy Clin Immunol. 2012; 12:602-8. [PubMed: 23026772]

20. Conley ME. Diagnostic guidelines--An International Consensus document. Clin Immunol. 1999; 93:189. [PubMed: 10600328]

21. Yel L. Selective IgA deficiency. J Clin Immunol. 2010; 30:10-6. [PubMed: 20101521]

22. Ballow M. Primary immunodeficiency disorders: antibody deficiency. J Allergy Clin Immunol. 2002; 109:581-91. [PubMed: 11941303]

23. Ludvigsson JF, Neovius M, Hammarstrom L. Association between IgA deficiency \& other autoimmune conditions: a population-based matched cohort study. J Clin Immunol. 2014; 34:44451. [PubMed: 24584841]

24. Ludvigsson JF, Neovius M, Hammarstrom L. Risk of Infections Among 2100 Individuals with IgA Deficiency: a Nationwide Cohort Study. J Clin Immunol. 2016; 36:134-40. [PubMed: 26739713]

25. Cunningham-Rundles C. Physiology of IgA and IgA deficiency. J Clin Immunol. 2001; 21:303-9. [PubMed: 11720003]

26. Wang Z, Yunis D, Irigoyen M, Kitchens B, Bottaro A, Alt FW, et al. Discordance between IgA switching at the DNA level and IgA expression at the mRNA level in IgA-deficient patients. Clin Immunol. 1999; 91:263-70. [PubMed: 10370371] 
27. Aghamohammadi A, Abolhassani H, Biglari M, Abolmaali S, Moazzami K, Tabatabaeiyan M, et al. Analysis of switched memory B cells in patients with IgA deficiency. Int Arch Allergy Immunol. 2011; 156:462-8. [PubMed: 21832837]

28. Litzman J, Burianova M, Thon V, Lokaj J. Progression of selective IgA deficiency to common variable immunodeficiency in a 16 year old boy. Allergol Immunopathol (Madr). 1996; 24:174-6. [PubMed: 8939274]

29. Espanol T, Catala M, Hernandez M, Caragol I, Bertran JM. Development of a common variable immunodeficiency in IgA-deficient patients. Clin Immunol Immunopathol. 1996; 80:333-5. [PubMed: 8811056]

30. Aghamohammadi A, Mohammadi J, Parvaneh N, Rezaei N, Moin M, Espanol T, et al. Progression of selective IgA deficiency to common variable immunodeficiency. Int Arch Allergy Immunol. 2008; 147:87-92. [PubMed: 18520152]

31. Castigli E, Wilson SA, Garibyan L, Rachid R, Bonilla F, Schneider L, et al. TACI is mutant in common variable immunodeficiency and IgA deficiency. Nat Genet. 2005; 37:829-34. [PubMed: 16007086]

32. Pan-Hammarstrom Q, Salzer U, Du L, Bjorkander J, Cunningham-Rundles C, Nelson DL, et al. Reexamining the role of TACI coding variants in common variable immunodeficiency and selective IgA deficiency. Nat Genet. 2007; 39:429-30. [PubMed: 17392797]

33. Bonilla FA, Khan DA, Ballas ZK, Chinen J, Frank MM, Hsu JT, et al. Practice parameter for the diagnosis and management of primary immunodeficiency. J Allergy Clin Immunol. 2015; 136:1186-205. e1-78. [PubMed: 26371839]

34. Wall LA, Dimitriades VR, Sorensen RU. Specific Antibody Deficiencies. Immunol Allergy Clin North Am. 2015; 35:659-70. [PubMed: 26454312]

35. Edwards E, Razvi S, Cunningham-Rundles C. IgA deficiency: clinical correlates and responses to pneumococcal vaccine. Clin Immunol. 2004; 111:93-7. [PubMed: 15093556]

36. Angulo I, Vadas O, Garcon F, Banham-Hall E, Plagnol V, Leahy TR, et al. Phosphoinositide 3kinase delta gene mutation predisposes to respiratory infection and airway damage. Science. 2013; 342:866-71. [PubMed: 24136356]

37. Aucouturier P, Bremard-Oury C, Griscelli C, Berthier M, Preud'homme JL. Serum IgG subclass deficiency in ataxia-telangiectasia. Clin Exp Immunol. 1987; 68:392-6. [PubMed: 3652519]

38. Ochs HD. The Wiskott-Aldrich syndrome. Clin Rev Allergy Immunol. 2001; 20:61-86. [PubMed: 11269229]

39. Al-Herz W, Notarangelo LD. Classification of primary immunodeficiency disorders: one-fits-all does not help anymore. Clin Immunol. 2012; 144:24-5. [PubMed: 22659031]

40. Cunningham-Rundles C, Maglione PJ. Common variable immunodeficiency. J Allergy Clin Immunol. 2012; 129:1425-6. e3. [PubMed: 22541363]

41. Cunningham-Rundles C. The many faces of common variable immunodeficiency. Hematology Am Soc Hematol Educ Program. 2012; 2012:301-5. [PubMed: 23233596]

42. Giovannetti A, Pierdominici M, Mazzetta F, Marziali M, Renzi C, Mileo AM, et al. Unravelling the complexity of T cell abnormalities in common variable immunodeficiency. J Immunol. 2007; 178:3932-43. [PubMed: 17339494]

43. Wehr C, Kivioja T, Schmitt C, Ferry B, Witte T, Eren E, et al. The EUROclass trial: defining subgroups in common variable immunodeficiency. Blood. 2008; 111:77-85. [PubMed: 17898316]

44. Chapel H, Lucas M, Lee M, Bjorkander J, Webster D, Grimbacher B, et al. Common variable immunodeficiency disorders: division into distinct clinical phenotypes. Blood. 2008; 112:277-86. [PubMed: 18319398]

45. Resnick ES, Moshier EL, Godbold JH, Cunningham-Rundles C. Morbidity and mortality in common variable immune deficiency over 4 decades. Blood. 2012; 119:1650-7. [PubMed: 22180439]

46. Maglione PJ. Autoimmune and Lymphoproliferative Complications of Common Variable Immunodeficiency. Curr Allergy Asthma Rep. 2016; 16:19. [PubMed: 26857017]

47. Kuehn HS, Ouyang W, Lo B, Deenick EK, Niemela JE, Avery DT, et al. Immune dysregulation in human subjects with heterozygous germline mutations in CTLA4. Science. 2014; 345:1623-7. [PubMed: 25213377] 
48. Schubert D, Bode C, Kenefeck R, Hou TZ, Wing JB, Kennedy A, et al. Autosomal dominant immune dysregulation syndrome in humans with CTLA4 mutations. Nat Med. 2014; 20:1410-6. [PubMed: 25329329]

49. Takahashi T, Tagami T, Yamazaki S, Uede T, Shimizu J, Sakaguchi N, et al. Immunologic selftolerance maintained by $\mathrm{CD} 25(+) \mathrm{CD} 4(+)$ regulatory $\mathrm{T}$ cells constitutively expressing cytotoxic $\mathrm{T}$ lymphocyte-associated antigen 4. J Exp Med. 2000; 192:303-10. [PubMed: 10899917]

50. Walker LS, Sansom DM. The emerging role of CTLA4 as a cell-extrinsic regulator of T cell responses. Nat Rev Immunol. 2011; 11:852-63. [PubMed: 22116087]

51. Lopez-Herrera G, Tampella G, Pan-Hammarstrom Q, Herholz P, Trujillo-Vargas CM, Phadwal K, et al. Deleterious mutations in LRBA are associated with a syndrome of immune deficiency and autoimmunity. Am J Hum Genet. 2012; 90:986-1001. [PubMed: 22608502]

52. Xu C, Min J. Structure and function of WD40 domain proteins. Protein Cell. 2011; 2:202-14. [PubMed: 21468892]

53. Lo B, Zhang K, Lu W, Zheng L, Zhang Q, Kanellopoulou C, et al. AUTOIMMUNE DISEASE. Patients with LRBA deficiency show CTLA4 loss and immune dysregulation responsive to abatacept therapy. Science. 2015; 349:436-40. [PubMed: 26206937]

54. Alkhairy OK, Abolhassani H, Rezaei N, Fang M, Andersen KK, Chavoshzadeh Z, et al. Spectrum of Phenotypes Associated with Mutations in LRBA. J Clin Immunol. 2016; 36:33-45. [PubMed: 26707784]

55. Gamez-Diaz L, August D, Stepensky P, Revel-Vilk S, Seidel MG, Noriko M, et al. The extended phenotype of LPS-responsive beige-like anchor protein (LRBA) deficiency. J Allergy Clin Immunol. 2016; 137:223-30. [PubMed: 26768763]

56. Lucas CL, Kuehn HS, Zhao F, Niemela JE, Deenick EK, Palendira U, et al. Dominant-activating germline mutations in the gene encoding the PI(3)K catalytic subunit p110delta result in $\mathrm{T}$ cell senescence and human immunodeficiency. Nat Immunol. 2014; 15:88-97. [PubMed: 24165795]

57. Crank MC, Grossman JK, Moir S, Pittaluga S, Buckner CM, Kardava L, et al. Mutations in PIK3CD can cause hyper IgM syndrome (HIGM) associated with increased cancer susceptibility. J Clin Immunol. 2014; 34:272-6. [PubMed: 24610295]

58. Milner JD, Vogel TP, Forbes L, Ma CA, Stray-Pedersen A, Niemela JE, et al. Early-onset lymphoproliferation and autoimmunity caused by germline STAT3 gain-of-function mutations. Blood. 2015; 125:591-9. [PubMed: 25359994]

59. Flanagan SE, Haapaniemi E, Russell MA, Caswell R, Lango Allen H, De Franco E, et al. Activating germline mutations in STAT3 cause early-onset multi-organ autoimmune disease. Nat Genet. 2014; 46:812-4. [PubMed: 25038750]

60. Haapaniemi EM, Kaustio M, Rajala HL, van Adrichem AJ, Kainulainen L, Glumoff V, et al. Autoimmunity, hypogammaglobulinemia, lymphoproliferation, and mycobacterial disease in patients with activating mutations in STAT3. Blood. 2015; 125:639-48. [PubMed: 25349174]

61. Vogel TP, Milner JD, Cooper MA. The Ying and Yang of STAT3 in Human Disease. J Clin Immunol. 2015; 35:615-23. [PubMed: 26280891]

62. Milner JD, Brenchley JM, Laurence A, Freeman AF, Hill BJ, Elias KM, et al. Impaired T(H)17 cell differentiation in subjects with autosomal dominant hyper-IgE syndrome. Nature. 2008; 452:7736. [PubMed: 18337720]

63. Notarangelo LD, Plebani A, Mazzolari E, Soresina A, Bondioni MP. Genetic causes of bronchiectasis: primary immune deficiencies and the lung. Respiration. 2007; 74:264-75. [PubMed: 17534129]

64. Aghamohammadi A, Allahverdi A, Abolhassani H, Moazzami K, Alizadeh H, Gharagozlou M, et al. Comparison of pulmonary diseases in common variable immunodeficiency and X-linked agammaglobulinaemia. Respirology. 2010; 15:289-95. [PubMed: 20051045]

65. Sweinberg SK, Wodell RA, Grodofsky MP, Greene JM, Conley ME. Retrospective analysis of the incidence of pulmonary disease in hypogammaglobulinemia. J Allergy Clin Immunol. 1991; 88:96-104. [PubMed: 2071789]

66. Chun JK, Lee TJ, Song JW, Linton JA, Kim DS. Analysis of clinical presentations of Bruton disease: a review of 20 years of accumulated data from pediatric patients at Severance Hospital. Yonsei Med J. 2008; 49:28-36. [PubMed: 18306466] 
67. Buckley RH. Pulmonary complications of primary immunodeficiencies. Paediatr Respir Rev. 2004; 5(Suppl A):S225-33. [PubMed: 14980276]

68. Eijkhout HW, van Der Meer JW, Kallenberg CG, Weening RS, van Dissel JT, Sanders LA, et al. The effect of two different dosages of intravenous immunoglobulin on the incidence of recurrent infections in patients with primary hypogammaglobulinemia. A randomized, double-blind, multicenter crossover trial. Ann Intern Med. 2001; 135:165-74. [PubMed: 11487483]

69. Stiehm ER, Chin TW, Haas A, Peerless AG. Infectious complications of the primary immunodeficiencies. Clin Immunol Immunopathol. 1986; 40:69-86. [PubMed: 3521971]

70. Janeway CA, Rosen FS. The gamma globulins. IV. Therapeutic uses of gamma globulin. N Engl J Med. 1966; 275:826-31. [PubMed: 4161939]

71. Lederman HM, Winkelstein JA. X-linked agammaglobulinemia: an analysis of 96 patients. Medicine (Baltimore). 1985; 64:145-56. [PubMed: 2581110]

72. Hermaszewski RA, Webster AD. Primary hypogammaglobulinaemia: a survey of clinical manifestations and complications. Q J Med. 1993; 86:31-42. [PubMed: 8438047]

73. Carsetti R, Rosado MM, Donnanno S, Guazzi V, Soresina A, Meini A, et al. The loss of IgM memory B cells correlates with clinical disease in common variable immunodeficiency. J Allergy Clin Immunol. 2005; 115:412-7. [PubMed: 15696104]

74. Micol R, Kayal S, Mahlaoui N, Beaute J, Brosselin P, Dudoit Y, et al. Protective effect of IgM against colonization of the respiratory tract by nontypeable Haemophilus influenzae in patients with hypogammaglobulinemia. J Allergy Clin Immunol. 2012; 129:770-7. [PubMed: 22153772]

75. Touw CM, van de Ven AA, de Jong PA, Terheggen-Lagro S, Beek E, Sanders EA, et al. Detection of pulmonary complications in common variable immunodeficiency. Pediatr Allergy Immunol. 2010; 21:793-805. [PubMed: 19912551]

76. Obregon RG, Lynch DA, Kaske T, Newell JD Jr. Kirkpatrick CH. Radiologic findings of adult primary immunodeficiency disorders. Contribution of CT. Chest. 1994; 106:490-5. [PubMed: 7774325]

77. Bates CA, Ellison MC, Lynch DA, Cool CD, Brown KK, Routes JM. Granulomatous-lymphocytic lung disease shortens survival in common variable immunodeficiency. J Allergy Clin Immunol. 2004; 114:415-21. [PubMed: 15316526]

78. Durandy A, Peron S, Fischer A. Hyper-IgM syndromes. Curr Opin Rheumatol. 2006; 18:369-76. [PubMed: 16763457]

79. Barker AF. Bronchiectasis. N Engl J Med. 2002; 346:1383-93. [PubMed: 11986413]

80. Cole PJ. Inflammation: a two-edged sword--the model of bronchiectasis. Eur J Respir Dis Suppl. 1986; 147:6-15. [PubMed: 3533593]

81. King PT, Holdsworth SR, Freezer NJ, Villanueva E, Gallagher M, Holmes PW. Outcome in adult bronchiectasis. COPD. 2005; 2:27-34. [PubMed: 17136958]

82. Twiss J, Stewart AW, Byrnes CA. Longitudinal pulmonary function of childhood bronchiectasis and comparison with cystic fibrosis. Thorax. 2006; 61:414-8. [PubMed: 16467074]

83. Martinez-Garcia MA, Soler-Cataluna JJ, Perpina-Tordera M, Roman-Sanchez P, Soriano J. Factors associated with lung function decline in adult patients with stable non-cystic fibrosis bronchiectasis. Chest. 2007; 132:1565-72. [PubMed: 17998359]

84. Oksenhendler E, Gerard L, Fieschi C, Malphettes M, Mouillot G, Jaussaud R, et al. Infections in 252 patients with common variable immunodeficiency. Clin Infect Dis. 2008; 46:1547-54. [PubMed: 18419489]

85. Howard V, Greene JM, Pahwa S, Winkelstein JA, Boyle JM, Kocak M, et al. The health status and quality of life of adults with X-linked agammaglobulinemia. Clin Immunol. 2006; 118:201-8. [PubMed: 16377251]

86. Kainulainen L, Varpula M, Liippo K, Svedstrom E, Nikoskelainen J, Ruuskanen O. Pulmonary abnormalities in patients with primary hypogammaglobulinemia. J Allergy Clin Immunol. 1999; 104:1031-6. [PubMed: 10550749]

87. Hurst JR, Workman S, Garcha DS, Seneviratne SL, Haddock JA, Grimbacher B. Activity, severity and impact of respiratory disease in primary antibody deficiency syndromes. J Clin Immunol. 2014; 34:68-75. [PubMed: 24136152] 
88. Griffith DE, Aksamit TR. Bronchiectasis and nontuberculous mycobacterial disease. Clin Chest Med. 2012; 33:283-95. [PubMed: 22640846]

89. Maglione PJ, Overbey JR, Radigan L, Bagiella E, Cunningham-Rundles C. Pulmonary radiologic findings in common variable immunodeficiency: clinical and immunological correlations. Ann Allergy Asthma Immunol. 2014; 113:452-9. [PubMed: 24880814]

90. Quinti I, Soresina A, Guerra A, Rondelli R, Spadaro G, Agostini C, et al. Effectiveness of immunoglobulin replacement therapy on clinical outcome in patients with primary antibody deficiencies: results from a multicenter prospective cohort study. J Clin Immunol. 2011; 31:31522. [PubMed: 21365217]

91. Gathmann B, Mahlaoui N, Ceredih, Gerard L, Oksenhendler E, Warnatz K, et al. Clinical picture and treatment of 2212 patients with common variable immunodeficiency. J Allergy Clin Immunol. 2014; 134:116-26. [PubMed: 24582312]

92. Hampson FA, Chandra A, Screaton NJ, Condliffe A, Kumararatne DS, Exley AR, et al. Respiratory disease in common variable immunodeficiency and other primary immunodeficiency disorders. Clin Radiol. 2012; 67:587-95. [PubMed: 22226567]

93. Aghamohammadi A, Cheraghi T, Gharagozlou M, Movahedi M, Rezaei N, Yeganeh M, et al. IgA deficiency: correlation between clinical and immunological phenotypes. J Clin Immunol. 2009; 29:130-6. [PubMed: 18683032]

94. Bjorkander J, Bake B, Oxelius VA, Hanson LA. Impaired lung function in patients with IgA deficiency and low levels of IgG2 or IgG3. N Engl J Med. 1985; 313:720-4. [PubMed: 4033696]

95. Stanley PJ, Corbo G, Cole PJ. Serum IgG subclasses in chronic and recurrent respiratory infections. Clin Exp Immunol. 1984; 58:703-8. [PubMed: 6509800]

96. De Gracia J, Rodrigo MJ, Morell F, Vendrell M, Miravitlles M, Cruz MJ, et al. IgG subclass deficiencies associated with bronchiectasis. Am J Respir Crit Care Med. 1996; 153:650-5. [PubMed: 8564113]

97. van Kessel DA, van Velzen-Blad H, van den Bosch JM, Rijkers GT. Impaired pneumococcal antibody response in bronchiectasis of unknown aetiology. Eur Respir J. 2005; 25:482-9. [PubMed: 15738292]

98. Chalmers JD, Aliberti S, Blasi F. Management of bronchiectasis in adults. Eur Respir J. 2015; 45:1446-62. [PubMed: 25792635]

99. Bonilla FA, Bernstein IL, Khan DA, Ballas ZK, Chinen J, Frank MM, et al. Practice parameter for the diagnosis and management of primary immunodeficiency. Ann Allergy Asthma Immunol. 2005; 94:S1-63. [PubMed: 15945566]

100. Welsh EJ, Evans DJ, Fowler SJ, Spencer S. Interventions for bronchiectasis: an overview of Cochrane systematic reviews. Cochrane Database Syst Rev. 2015:CD010337. [PubMed: 26171905]

101. Altenburg J, de Graaff CS, Stienstra Y, Sloos JH, van Haren EH, Koppers RJ, et al. Effect of azithromycin maintenance treatment on infectious exacerbations among patients with non-cystic fibrosis bronchiectasis: the BAT randomized controlled trial. JAMA. 2013; 309:1251-9. [PubMed: 23532241]

102. Wong C, Jayaram L, Karalus N, Eaton T, Tong C, Hockey H, et al. Azithromycin for prevention of exacerbations in non-cystic fibrosis bronchiectasis (EMBRACE): a randomised, double-blind, placebo-controlled trial. Lancet. 2012; 380:660-7. [PubMed: 22901887]

103. Fan LC, Lu HW, Wei P, Ji XB, Liang S, Xu JF. Effects of long-term use of macrolides in patients with non-cystic fibrosis bronchiectasis: a meta-analysis of randomized controlled trials. BMC Infect Dis. 2015; 15:160. [PubMed: 25888483]

104. Prasse A, Kayser G, Warnatz K. Common variable immunodeficiency-associated granulomatous and interstitial lung disease. Curr Opin Pulm Med. 2013; 19:503-9. [PubMed: 23880700]

105. Maglione PJ, Overbey JR, Cunningham-Rundles C. Progression of Common Variable Immunodeficiency Interstitial Lung Disease Accompanies Distinct Pulmonary and Laboratory Findings. J Allergy Clin Immunol Pract. 2015; 3:941-50. [PubMed: 26372540]

106. Reichenberger F, Wyser C, Gonon M, Cathomas G, Tamm M. Pulmonary mucosa-associated lymphoid tissue lymphoma in a patient with common variable immunodeficiency syndrome. Respiration. 2001; 68:109-12. [PubMed: 11223743] 
107. Maglione PJ, Ko HM, Beasley MB, Strauchen JA, Cunningham-Rundles C. Tertiary lymphoid neogenesis is a component of pulmonary lymphoid hyperplasia in patients with common variable immunodeficiency. J Allergy Clin Immunol. 2014; 133:535-42. [PubMed: 24131823]

108. Roca B, Ferran G, Simon E, Cortes V. Lymphoid hyperplasia of the lung and Evans' syndrome in IgA deficiency. Am J Med. 1999; 106:121-2. [PubMed: 10320128]

109. Ozkan H, Atlihan F, Genel F, Targan S, Gunvar T. IgA and/or IgG subclass deficiency in children with recurrent respiratory infections and its relationship with chronic pulmonary damage. $\mathrm{J}$ Investig Allergol Clin Immunol. 2005; 15:69-74.

110. Quartier P, Bustamante J, Sanal O, Plebani A, Debre M, Deville A, et al. Clinical, immunologic and genetic analysis of 29 patients with autosomal recessive hyper-IgM syndrome due to Activation-Induced Cytidine Deaminase deficiency. Clin Immunol. 2004; 110:22-9. [PubMed: 14962793]

111. Cabral-Marques O, Klaver S, Schimke LF, Ascendino EH, Khan TA, Pereira PV, et al. First report of the Hyper-IgM syndrome Registry of the Latin American Society for Immunodeficiencies: novel mutations, unique infections, and outcomes. J Clin Immunol. 2014; 34:146-56. [PubMed: 24402618]

112. Costa-Carvalho BT, Wandalsen GF, Pulici G, Aranda CS, Sole D. Pulmonary complications in patients with antibody deficiency. Allergol Immunopathol (Madr). 2011; 39:128-32. [PubMed: 21339034]

113. Toth B, Volokha A, Mihas A, Pac M, Bernatowska E, Kondratenko I, et al. Genetic and demographic features of X-linked agammaglobulinemia in Eastern and Central Europe: a cohort study. Mol Immunol. 2009; 46:2140-6. [PubMed: 19419768]

114. Lee PP, Chen TX, Jiang LP, Chan KW, Yang W, Lee BW, et al. Clinical characteristics and genotypephenotype correlation in 62 patients with X-linked agammaglobulinemia. J Clin Immunol. 2010; 30:121-31. [PubMed: 19904586]

115. Aadam Z, Kechout N, Barakat A, Chan KW, Ben-Ali M, Ben-Mustapha I, et al. X-Linked Agammagobulinemia in a Large Series of North African Patients: Frequency, Clinical Features and Novel BTK Mutations. J Clin Immunol. 2016; 36:187-94. [PubMed: 26931785]

116. Garcia-Garcia E, Staines-Boone AT, Vargas-Hernandez A, Gonzalez-Serrano ME, Carrillo-Tapia E, Mogica-Martinez D, et al. Clinical and mutational features of X-linked agammaglobulinemia in Mexico. Clin Immunol. 2016; 165:38-44. [PubMed: 26960951]

117. Carrillo J, Restrepo CS, Rosado de Christenson M, Ojeda Leon P, Lucia Rivera A, Koss MN. Lymphoproliferative lung disorders: a radiologic-pathologic overview. Part I: Reactive disorders. Semin Ultrasound CT MR. 2013; 34:525-34. [PubMed: 24332204]

118. Ardeniz O, Cunningham-Rundles C. Granulomatous disease in common variable immunodeficiency. Clin Immunol. 2009; 133:198-207. [PubMed: 19716342]

119. Roberton BJ, Hansell DM. Organizing pneumonia: a kaleidoscope of concepts and morphologies. Eur Radiol. 2011; 21:2244-54. [PubMed: 21744289]

120. Rao N, Mackinnon AC, Routes JM. Granulomatous and lymphocytic interstitial lung disease: a spectrum of pulmonary histopathologic lesions in common variable immunodeficiency-histologic and immunohistochemical analyses of 16 cases. Hum Pathol. 2015; 46:1306-14. [PubMed: 26138782]

121. Tian X, Yi ES, Ryu JH. Lymphocytic interstitial pneumonia and other benign lymphoid disorders. Semin Respir Crit Care Med. 2012; 33:450-61. [PubMed: 23001800]

122. Guinee DG Jr. Update on nonneoplastic pulmonary lymphoproliferative disorders and related entities. Arch Pathol Lab Med. 2010; 134:691-701. [PubMed: 20441500]

123. Corcoran LM, Tarlinton DM. Regulation of germinal center responses, memory B cells and plasma cell formation-an update. Curr Opin Immunol. 2016; 39:59-67. [PubMed: 26799208]

124. Jones GW, Jones SA. Ectopic lymphoid follicles: inducible centres for generating antigen-specific immune responses within tissues. Immunology. 2016; 147:141-51. [PubMed: 26551738]

125. Boursiquot JN, Gerard L, Malphettes M, Fieschi C, Galicier L, Boutboul D, et al. Granulomatous disease in CVID: retrospective analysis of clinical characteristics and treatment efficacy in a cohort of 59 patients. J Clin Immunol. 2013; 33:84-95. [PubMed: 22986767] 
126. Chase NM, Verbsky JW, Hintermeyer MK, Waukau JK, Tomita-Mitchell A, Casper JT, et al. Use of combination chemotherapy for treatment of granulomatous and lymphocytic interstitial lung disease (GLILD) in patients with common variable immunodeficiency (CVID). J Clin Immunol. 2013; 33:30-9. [PubMed: 22930256]

127. Torigian DA, LaRosa DF, Levinson AI, Litzky LA, Miller WT Jr. Granulomatous-lymphocytic interstitial lung disease associated with common variable immunodeficiency: CT findings. J Thorac Imaging. 2008; 23:162-9. [PubMed: 18728542]

128. Bondioni MP, Soresina A, Lougaris V, Gatta D, Plebani A, Maroldi R. Common variable immunodeficiency: computed tomography evaluation of bronchopulmonary changes including nodular lesions in 40 patients. Correlation with clinical and immunological data. J Comput Assist Tomogr. 2010; 34:395-401. [PubMed: 20498543]

129. van de Ven AA, Warnatz K. The autoimmune conundrum in common variable immunodeficiency disorders. Curr Opin Allergy Clin Immunol. 2015; 15:514-24. [PubMed: 26485099]

130. Allenspach E, Torgerson TR. Autoimmunity and Primary Immunodeficiency Disorders. J Clin Immunol. 2016; 36(Suppl 1):57-67. [PubMed: 27210535]

131. da Silva SP, Resnick E, Lucas M, Lortan J, Patel S, Cunningham-Rundles C, et al. Lymphoid proliferations of indeterminate malignant potential arising in adults with common variable immunodeficiency disorders: unusual case studies and immunohistological review in the light of possible causative events. J Clin Immunol. 2011; 31:784-91. [PubMed: 21744182]

132. Reina D, Roig Vilaseca D, Torrente-Segarra V, Cerda D, Castellvi I, Diaz Torne C, et al. Sjogren's syndrome-associated interstitial lung disease: A multicenter study. Reumatol Clin. 2015

133. Shi JH, Liu HR, Xu WB, Feng RE, Zhang ZH, Tian XL, et al. Pulmonary manifestations of Sjogren's syndrome. Respiration. 2009; 78:377-86. [PubMed: 19390161]

134. Wheat WH, Cool CD, Morimoto Y, Rai PR, Kirkpatrick CH, Lindenbaum BA, et al. Possible role of human herpesvirus 8 in the lymphoproliferative disorders in common variable immunodeficiency. J Exp Med. 2005; 202:479-84. [PubMed: 16103407]

135. Fajgenbaum DC, van Rhee F, Nabel CS. HHV-8-negative, idiopathic multicentric Castleman disease: novel insights into biology, pathogenesis, and therapy. Blood. 2014; 123:2924-33. [PubMed: 24622327]

136. Andiman WA, Eastman R, Martin K, Katz BZ, Rubinstein A, Pitt J, et al. Opportunistic lymphoproliferations associated with Epstein-Barr viral DNA in infants and children with AIDS. Lancet. 1985; 2:1390-3. [PubMed: 2867394]

137. Barbera JA, Hayashi S, Hegele RG, Hogg JC. Detection of Epstein-Barr virus in lymphocytic interstitial pneumonia by in situ hybridization. Am Rev Respir Dis. 1992; 145:940-6. [PubMed: 1313215]

138. San-Juan R, Comoli P, Caillard S, Moulin B, Hirsch HH, Meylan P, et al. Epstein-Barr virusrelated post-transplant lymphoproliferative disorder in solid organ transplant recipients. Clin Microbiol Infect. 2014; 20(Suppl 7):109-18. [PubMed: 24475976]

139. Unger S, Seidl M, Schmitt-Graeff A, Bohm J, Schrenk K, Wehr C, et al. Ill-defined germinal centers and severely reduced plasma cells are histological hallmarks of lymphadenopathy in patients with common variable immunodeficiency. J Clin Immunol. 2014; 34:615-26. [PubMed: 24789743]

140. Chiu CY. Viral pathogen discovery. Curr Opin Microbiol. 2013; 16:468-78. [PubMed: 23725672]

141. Verbsky JW, Routes JM. Sarcoidosis and common variable immunodeficiency: similarities and differences. Semin Respir Crit Care Med. 2014; 35:330-5. [PubMed: 25007085]

142. de Jager M, Blokx W, Warris A, Bergers M, Link M, Weemaes C, et al. Immunohistochemical features of cutaneous granulomas in primary immunodeficiency disorders: a comparison with cutaneous sarcoidosis. J Cutan Pathol. 2008; 35:467-72. [PubMed: 18201241]

143. Reddy DL, Venter WD, Pather S. Patterns of Lymph Node Pathology; Fine Needle Aspiration Biopsy as an Evaluation Tool for Lymphadenopathy: A Retrospective Descriptive Study Conducted at the Largest Hospital in Africa. PLoS One. 2015; 10:e0130148. [PubMed: 26091519]

144. Ko HM, da Cunha Santos G, Darling G, Pierre A, Yasufuku K, Boerner SL, et al. Diagnosis and subclassification of lymphomas and non-neoplastic lesions involving mediastinal lymph nodes 
using endobronchial ultrasound-guided transbronchial needle aspiration. Diagn Cytopathol. 2013; 41:1023-30. [PubMed: 21630485]

145. Aghamohammadi A, Moin M, Kouhi A, Mohagheghi MA, Shirazi A, Rezaei N, et al. Chromosomal radiosensitivity in patients with common variable immunodeficiency. Immunobiology. 2008; 213:447-54. [PubMed: 18472053]

146. Palanduz S, Palanduz A, Yalcin I, Somer A, Ones U, Ustek D, et al. In vitro chromosomal radiosensitivity in common variable immune deficiency. Clin Immunol Immunopathol. 1998; 86:180-2. [PubMed: 9473380]

147. Vorechovsky I, Scott D, Haeney MR, Webster DA. Chromosomal radiosensitivity in common variable immune deficiency. Mutat Res. 1993; 290:255-64. [PubMed: 7694117]

148. Arish N, Eldor R, Fellig Y, Bogot N, Laxer U, Izhar U, et al. Lymphocytic interstitial pneumonia associated with common variable immunodeficiency resolved with intravenous immunoglobulins. Thorax. 2006; 61:1096-7. [PubMed: 17114373]

149. Hayakawa H, Sato A, Imokawa S, Toyoshima M, Chida K, Iwata M. Bronchiolar disease in rheumatoid arthritis. Am J Respir Crit Care Med. 1996; 154:1531-6. [PubMed: 8912776]

150. Ryu JH, Myers JL, Swensen SJ. Bronchiolar disorders. Am J Respir Crit Care Med. 2003; 168:1277-92. [PubMed: 14644923]

151. Aerni MR, Vassallo R, Myers JL, Lindell RM, Ryu JH. Follicular bronchiolitis in surgical lung biopsies: clinical implications in 12 patients. Respir Med. 2008; 102:307-12. [PubMed: 17997299]

152. Kohler PF, Cook RD, Brown WR, Manguso RL. Common variable hypogammaglobulinemia with T-cell nodular lymphoid interstitial pneumonitis and B-cell nodular lymphoid hyperplasia: different lymphocyte populations with a similar response to prednisone therapy. J Allergy Clin Immunol. 1982; 70:299-305. [PubMed: 6981662]

153. Davies CW, Juniper MC, Gray W, Gleeson FV, Chapel HM, Davies RJ. Lymphoid interstitial pneumonitis associated with common variable hypogammaglobulinaemia treated with cyclosporin A. Thorax. 2000; 55:88-90. [PubMed: 10607809]

154. Thatayatikom A, Thatayatikom S, White AJ. Infliximab treatment for severe granulomatous disease in common variable immunodeficiency: a case report and review of the literature. Ann Allergy Asthma Immunol. 2005; 95:293-300. [PubMed: 16200822]

155. Franxman TJ, Howe LE, Baker JR Jr. Infliximab for treatment of granulomatous disease in patients with common variable immunodeficiency. J Clin Immunol. 2014; 34:820-7. [PubMed: 25062849]

156. Carson KR, Evens AM, Richey EA, Habermann TM, Focosi D, Seymour JF, et al. Progressive multifocal leukoencephalopathy after rituximab therapy in HIV-negative patients: a report of 57 cases from the Research on Adverse Drug Events and Reports project. Blood. 2009; 113:4834 40. [PubMed: 19264918]

157. Chien SH, Liu CJ, Hong YC, Teng CJ, Hu YW, Shen CC, et al. Use of azathioprine for graft-vshost disease is the major risk for development of secondary malignancies after haematopoietic stem cell transplantation: a nationwide population-based study. Br J Cancer. 2015; 112:177-84. [PubMed: 25314066]

158. Burton CM, Milman N, Andersen CB, Marquart H, Iversen M. Common variable immune deficiency and lung transplantation. Scand J Infect Dis. 2007; 39:362-7. [PubMed: 17454905] 


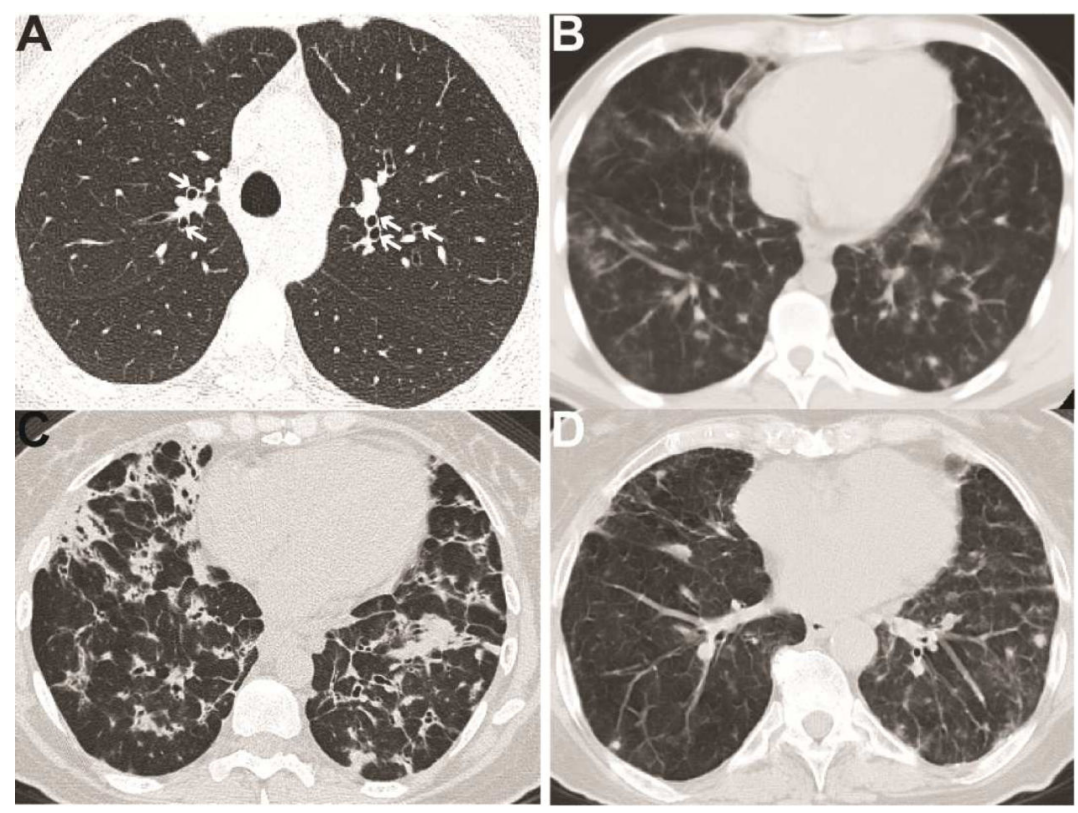

Figure 1. Radiologic findings of lung disease in PAD

A. Bronchiectasis (marked by white arrows) in a patient with CVID. B. CVID patient with bilateral pulmonary nodules and mediastinal lymphadenopathy. C. CVID patient with innumerable nodular opacities, bronchiectasis, and mediastinal lymphadenopathy. D. Patient with IgA/IgG2 deficiency (IgA < 10 mg/dL, IgG 997 mg/dL, IgG2 < 16 mg/dL) demonstrating multiple non-calcified lung nodules. 


\section{Bronchiectasis}

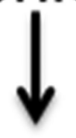

Initiate one or more of the following:

1. Inhaled corticosteroid +/- LABA

2. Long-term macrolide use

3. Increase lgG replacement dosage

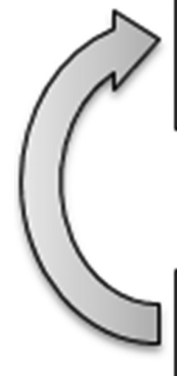
(trough $1000 \mathrm{mg} / \mathrm{dL}$ )

4. Pulmonary rehabilitation

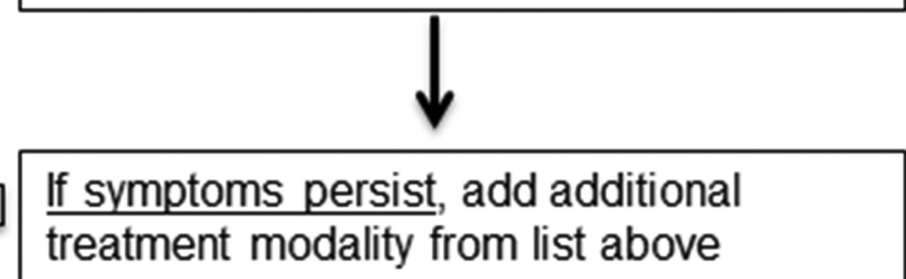

Figure 2. Therapeutic approach for bronchiectasis in PAD

Treatment algorithm for management of bronchiectasis in PAD patients. LABA, long-acting $\beta$-agonist. 


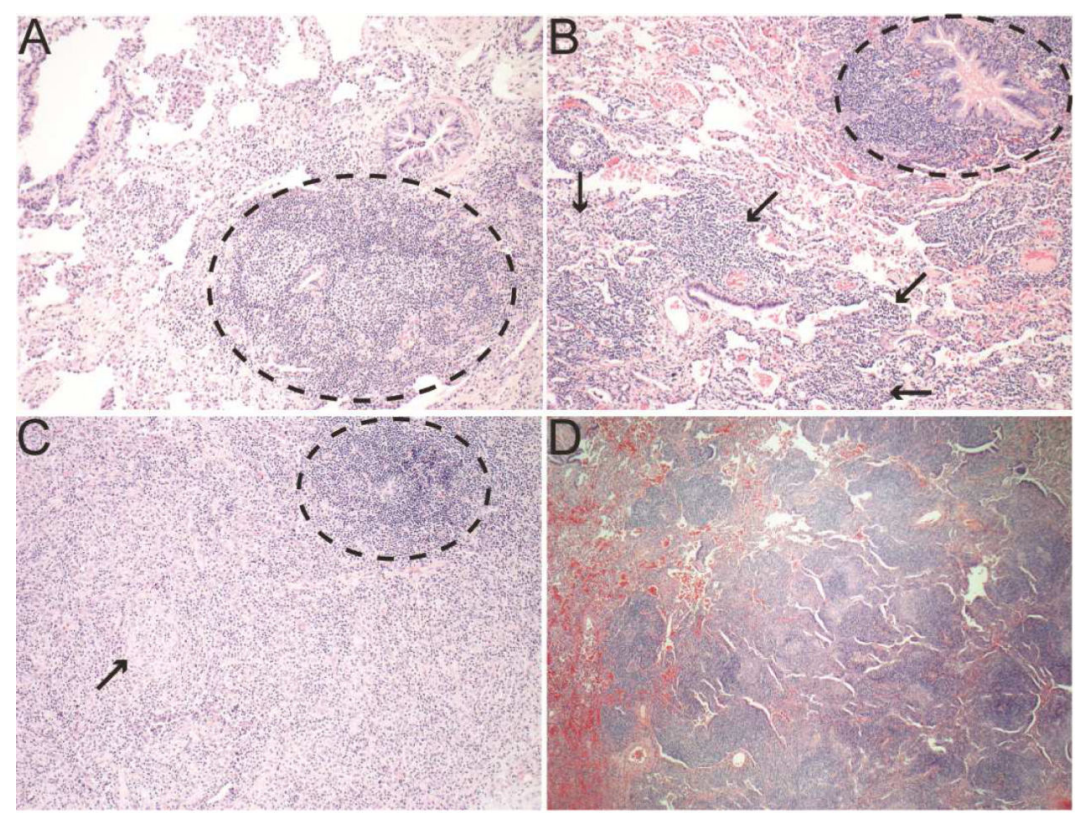

Figure 3. Pulmonary pathology from CVID ILD patients

A. Lymphoid follicle (black circle) near the airway with minimal involvement of other parenchyma indicating follicular bronchiolitis (200X). B. Follicular bronchiolitis (black circle) noted with lymphocytes in the interstitium and expanding the alveolar septum characteristic of LIP (black arrows, 200X). C. Granulomatous inflammation with circumscribed granuloma (black arrow) and ectopic lymphoid follicle (black circle, 200X). D. Well-demarcated lymphoid follicles characteristic of nodular lymphoid hyperplasia (100X). 

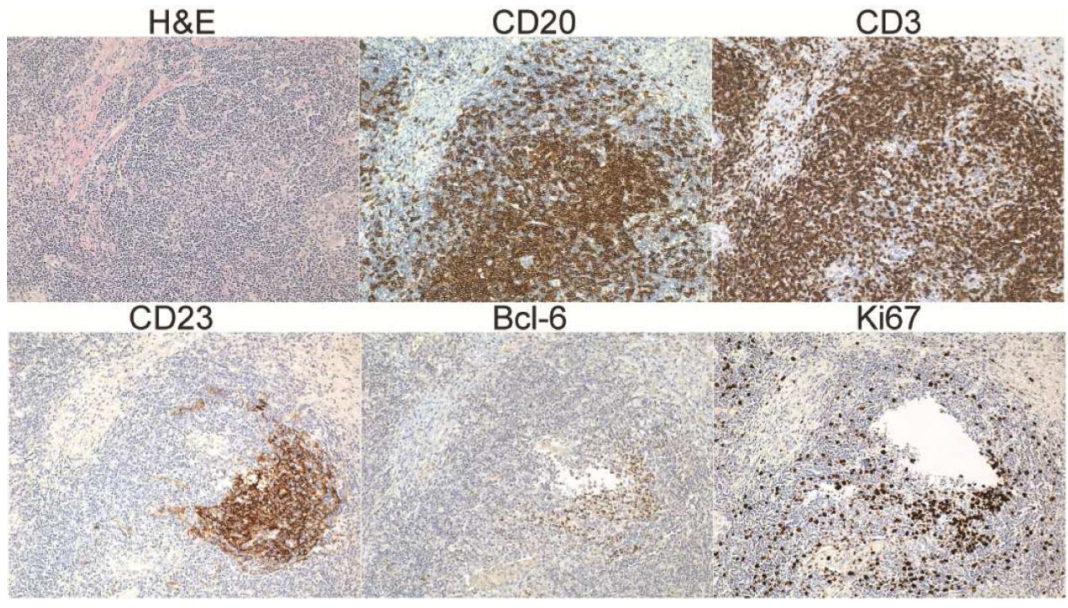

Figure 4. PLH contains ectopic lymphoid follicles in CVID

Wedge biopsy from CVID patient with LIP demonstrating diffuse lymphocytic infiltrate (H\&E) with ectopic B cell follicles (CD20) circumscribed by T cells (CD3) and containing follicular dendritic cells (CD23), a germinal center marker (Bcl-6), and proliferating cells (Ki67). 


\section{Interstitial Lung Disease demonstrated on CT chest $\downarrow$}

Initial therapeutic options at physician discretion:

1. Inhaled corticosteroid +/- LABA

2. Long-term macrolide use

3. Increase $\operatorname{lgG}$ replacement dosage (trough $1000 \mathrm{mg} / \mathrm{dL}$ )
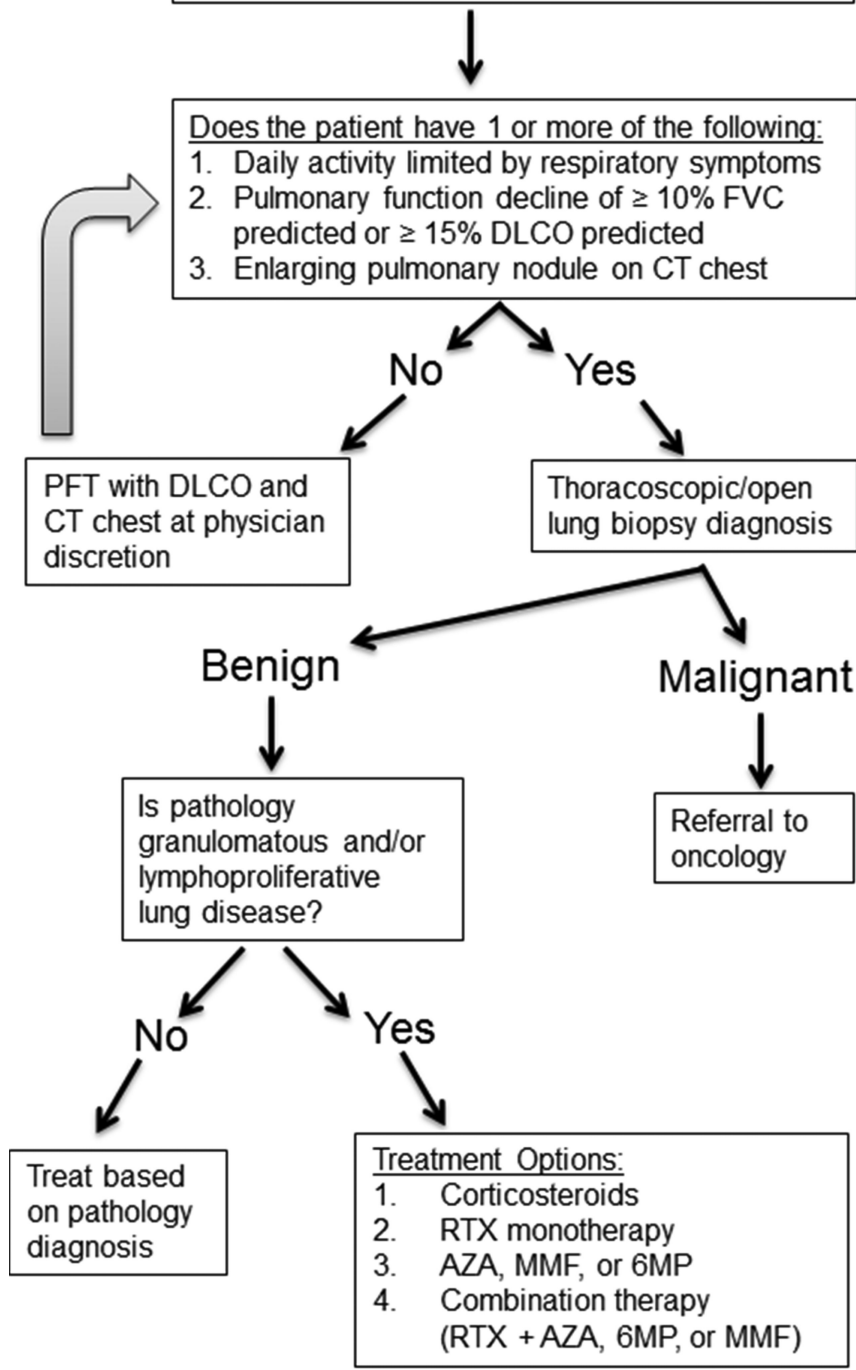

Figure 5. Therapeutic approach for ILD in PAD

Treatment algorithm for management of ILD in PAD patients. AZA, azathioprine; LABA, long-acting $\beta$-agonist; MMF, mycophenolate mofetil; RTX, rituximab; 6MP, 6mercaptopurine. 
Table I

Lung pathology most commonly associated with primary antibody deficiency.

\begin{tabular}{|c|c|}
\hline Pathology & Description \\
\hline Non-necrotizing granulomatous inflammation & $\begin{array}{l}\text { Inflammation characterized by circumscribed organized collections of } \\
\text { macrophages (histiocytes) }+/- \text { giant cells. Non-necrotizing granulomas lack areas } \\
\text { of central necrosis and may be a feature of many diseases both infectious and non- } \\
\text { infectious. }\end{array}$ \\
\hline Organizing pneumonia & $\begin{array}{l}\text { Non-specific response to lung injury characterized by organizing fibroblastic } \\
\text { tissue within alveolar spaces known as Masson bodies. }\end{array}$ \\
\hline \multicolumn{2}{|l|}{ Benign lymphoproliferative lung disease } \\
\hline Nodular lymphoid hyperplasia & $\begin{array}{l}\text { Well-circumscribed area of benign lymphoid hyperplasia effacing the lung } \\
\text { parenchyma with well-demarcated follicles. The process is polyclonal and the } \\
\text { relationship to lymphoma is unclear. }\end{array}$ \\
\hline Follicular bronchiolitis & $\begin{array}{l}\text { Lymphoid hyperplasia around airways with minimal involvement of the alveolar } \\
\text { septa. }\end{array}$ \\
\hline Lymphocytic interstitial pneumonia (LIP) & $\begin{array}{l}\text { Thought to represent part of a spectrum of pulmonary lymphoid hyperplasia with } \\
\text { follicular bronchiolitis but is characterized by lymphocytes in the interstitium } \\
\text { expanding the alveolar septum. May contain non-necrotizing granulomatous } \\
\text { inflammation. Organizing pneumonia is infrequent. }\end{array}$ \\
\hline $\begin{array}{c}\text { Granulomatous lymphocytic interstitial lung disease } \\
\text { (GLILD) }\end{array}$ & $\begin{array}{c}\text { Similar to LIP, but has more frequent, larger granulomas and large areas of } \\
\text { organizing pneumonia are often present. }\end{array}$ \\
\hline
\end{tabular}




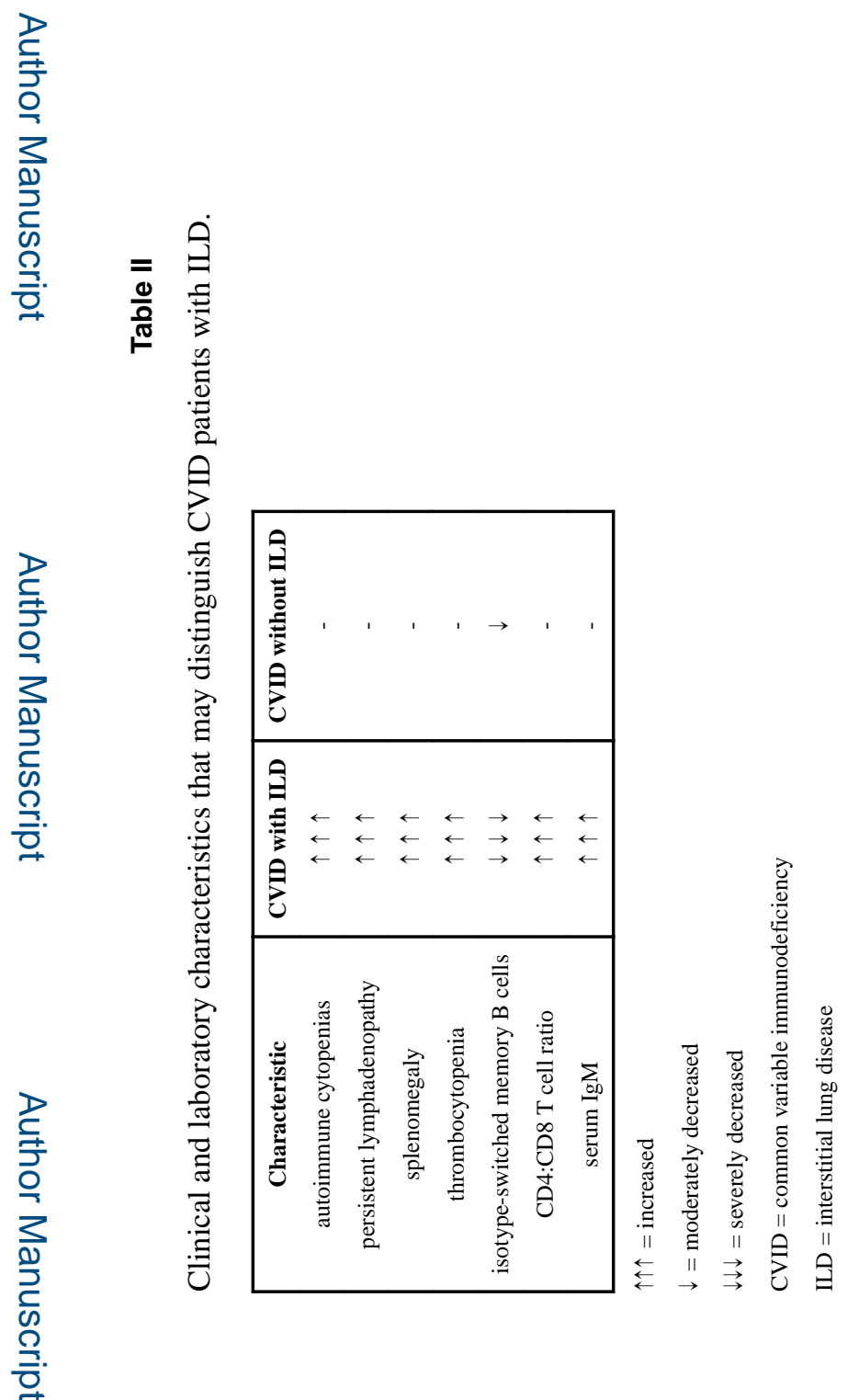

J Allergy Clin Immunol Pract. Author manuscript; available in PMC 2017 November 01. 
Table III

Clinical and radiological features differentiating CVID ILD and sarcoidosis.

\begin{tabular}{|c|c|c|}
\hline Clinical Feature & CVID ILD & Sarcoidosis \\
\hline Low serum IgG & $\uparrow \uparrow \uparrow$ & $\downarrow \downarrow \downarrow$ \\
\hline Autoimmune cytopenias (AIHA, ITP) & $\uparrow \uparrow \uparrow$ & $\downarrow \downarrow \downarrow$ \\
\hline Splenomegaly & $\uparrow \uparrow \uparrow$ & $\downarrow \downarrow \downarrow$ \\
\hline Nodular regenerative hyperplasia of the liver & $\uparrow \uparrow \uparrow$ & $\downarrow \downarrow \downarrow$ \\
\hline Lymphocytic interstitial pneumonia & $\uparrow \uparrow \uparrow$ & $\downarrow \downarrow \downarrow$ \\
\hline Follicular bronchiolitis & $\uparrow \uparrow \uparrow$ & $\downarrow \downarrow \downarrow$ \\
\hline Recurrent infection & $\uparrow \uparrow \uparrow$ & $\downarrow \downarrow \downarrow$ \\
\hline High BAL CD4:CD8 ratio & $\downarrow \downarrow \downarrow$ & $\downarrow \downarrow \downarrow$ \\
\hline Low percentage of IgM-IgD-CD27+ memory B cells & $\uparrow \uparrow \uparrow$ & \\
\hline Radiological Feature & & small (>1 cm is uncommon) \\
\hline Nodule size & large $(>1 \mathrm{~cm}$ is common) & apical lung zones, perilymphatic \\
\hline Nodule location & random distribution & $\downarrow \downarrow \downarrow$ \\
\hline Associated with bronchiectasis & $\uparrow \uparrow \uparrow$ & \\
\hline
\end{tabular}

$\uparrow \uparrow \uparrow=$ increased likelihood

$\downarrow \downarrow \downarrow=$ decreased likelihood

AIHA = autoimmune hemolytic anemia

$\mathrm{BAL}=$ bronchoalveolar lavage

ITP = immune thrombocytopenic purpura 